\title{
Steel Reinforced Grout for Strengthening of RC T-section Beams Deficient in Shear
}

\author{
Tadesse Wakjira \\ twakjira@qu.edu.qa \\ Department of Civil and Architectural Engineering, Qatar University, Doha, Qatar \\ Usama Ebead \\ uebead@qu.edu.qa \\ Department of Civil and Architectural Engineering, Qatar University, Doha, Qatar
}

\begin{abstract}
Reinforced concrete (RC) beams are bound to lose their strength while in service due to numerous causes. Thus, proper strengthening and rehabilitation techniques are required to restore the strength and extend the service life of the structures. Steel reinforced grout (SRG) has recently been introduced as an efficient and economical strengthening solution, however, the study on its application for the strengthening of shear-deficient $\mathrm{RC}$ beams is scarce. Thus, this paper is aimed to investigate the efficacy of SRG for shear strengthening of RC beams with the focus on SRG/stirrups interaction. Six T-cross section beams were grouped into three series based on their internal shear reinforcement ratio and tested under three-point bending. Each series comprised of one reference and one SRG-strengthened beam. The test results revealed that SRG laminates are an effective technique to increase the shear capacity of RC beams. Up to $71 \%$ increase in the load-carrying capacity of the strengthened beams was achieved. The increase in the internal shear reinforcement has shown to reduce the shear-strengthening performance of SRG.
\end{abstract}

Keywords: Strengthening; Steel reinforced grout (SRG); Beam; Shear; SRG/stirrups interaction

\section{INTRODUCTION}

The geographical location and weather of Gulf countries, including Qatar, expose their key infrastructure to severe deterioration due to the proximity to seawater, humidity, and high temperatures. Therefore, deterioration due to such factors necessitates the need for effective strengthening techniques to extend the service life of the infrastructure. Different strengthening methods were developed through time with advanced strengthening material gaining popularity over traditional ones owing to their favorable advantages such as high strength-to-weight ratio, high resistance to corrosion, and speed and ease of installation. In this context, fiber-reinforced polymer and recently fabric reinforced matrix have shown to be effective strengthening techniques for both reinforced concrete and masonry structures (Al-Saadi et al., 2019; Carozzi et al., 2017; Elsanadedy et al., 2019; Koutas et al., 2019; Marcinczak \& Trapko, 2019; Oller et al., 2019; Wakjira \& Ebead, 2018; Younis et al., 2017). However, the high cost associated with these materials limits their widespread use. An alternative strengthening system using steel reinforced grout has recently developed as a cost-effective strengthening solution. Steel reinforced grout has shown to be an effective strengthening solution for 
$\mathrm{RC}$ beams in flexure and shear. The first study on the use of SRG/SRP as a strengthening solution dated back to 2004 for flexural strengthening of RC beams (Barton et al., 2005; Huang et al., 2005; Wobbe et al., 2004). Since then, successful applications of SRG/ SRP have been reported in various experimental studies for strengthening of different structural members, including RC beams (Napoli \& Realfonzo, 2015; Prota et al., 2006; Wakjira \& Ebead, 2019), RC slabs (Annalisa et al., 2015; Hadad \& Nanni, 2018), column confinement (Thermou \& Hajirasouliha, 2018), and masonry structures (De Santis et al., 2018; De Santis \& De Felice, 2015). Theoretical prediction of flexural strengthened RC beams using SRG/SRP system was also presented in a previous research contribution (Bencardino \& Condello, 2015). With regard to the RC beams strengthened with SRG, the experimental studies to date are mainly dedicated to the strengthening of beams in flexure (Napoli \& Realfonzo, 2015; De Santis et al., 2016). However, the studies devoted to the strengthening of shear deficient RC beams are very limited (Thermou et al., 2019; Wakjira \& Ebead, 2019).

Thus, the proposed research investigates the application of SRG for the strengthening of RC beams in shear. The work will contribute to enriching the relatively limited research available on the application of SRG for strengthening of RC structures. The main focus is to investigate the shear behavior of SRG strengthened T-beams and the SRG/stirrups interaction. With this in aim, three control beams and three SRG-strengthened RC T-section beams were prepared and tested under three-point loading. The experimental results confirmed the potential application of SRG for shear strengthening of RC beams.

\section{EXPERIMENTAL PROGRAM}

\subsection{Material}

The beams were cast using ready-mixed concrete with an average compressive strength of $34 \mathrm{MPa}$ as obtained from the direct compressive test.

The beams were internally reinforced with $25 \mathrm{~mm}$ diameter deformed top bars and $16 \mathrm{~mm}$ diameter deformed bottom bars as tensile and compressive reinforcements, respectively. The shear reinforcement outside the shear span was $8 \mathrm{~mm}$ diameter stirrups spaced at $75 \mathrm{~mm}$, while outside the shear span three different shear reinforcements were used (none, $6 \mathrm{~mm}$ at $300 \mathrm{~mm}$, and $6 \mathrm{~mm}$ at $150 \mathrm{~mm}$ ). The properties of the reinforcement bars are listed in Table 1.

Table 1: Properties of the steel reinforcement bars

\begin{tabular}{|l|l|l|l|l|}
\hline Description & \multicolumn{2}{l|}{$\begin{array}{l}\text { Longitudinal reinforce- } \\
\text { ment bars }\end{array}$} & \multicolumn{2}{l|}{ Stirrups } \\
\hline Bar diameter & $16 \mathrm{~mm}$ & $25 \mathrm{~mm}$ & $6 \mathrm{~mm}$ & $8 \mathrm{~mm}$ \\
\hline Yield strength & 562 & 588 & 234 & 535 \\
\hline Yield strain (\%) & 0.233 & 0.241 & 0.117 & 0.258 \\
\hline Modulus of elasticity, GPa & 241 & 244 & 207 & 207 \\
\hline
\end{tabular}

The SRG system was composed of geo-mortar reinforced with steel fabrics. Figure 1 shows the steel fabrics used in this study, which were made of high strength steel cords obtained by assembling five filaments. Two of the filaments were wrapped around 
another three straight filaments to form the steel fabrics, as shown in Fig. 1. The average mechanical properties of the steel fabrics and the associated geo-mortar are listed in Table 2.

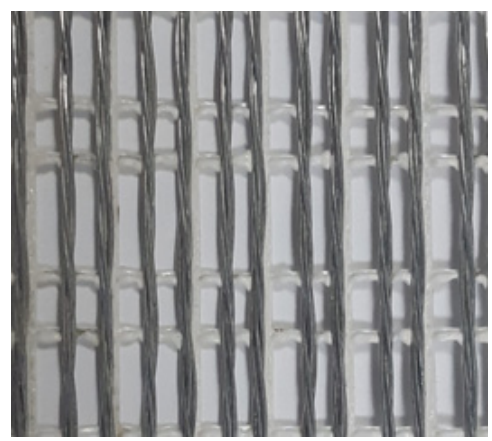

Figure 1: Geometry of the steel fabric used in the study

Table 2: Properties of steel fabrics and mortar

\begin{tabular}{|l|l|l|l|l|l|l|l|l|}
\hline Description & $\begin{array}{l}\text { Thickness } \\
(\mathrm{mm})\end{array}$ & $\begin{array}{l}\text { Cord } \\
\text { area } \\
\left(\mathrm{mm}^{2}\right)\end{array}$ & $\begin{array}{l}\text { Weight of } \\
\text { fiber }(\mathrm{g} / \\
\left.\mathrm{m}^{2}\right)\end{array}$ & $\begin{array}{l}\text { Density } \\
(\mathrm{cords} / \\
\mathrm{cm})\end{array}$ & $\begin{array}{l}\text { Tensile } \\
\text { strength } \\
(\mathrm{MPa})\end{array}$ & $\begin{array}{l}\text { Elastic } \\
\text { modulus } \\
(\mathrm{GPa})\end{array}$ & $\begin{array}{l}\text { Compressive } \\
\text { strength } \\
\text { (average of 28 } \\
\mathrm{d}), \mathrm{MPa}\end{array}$ & $\begin{array}{l}\text { Bond strength } \\
(\text { average of 28 } \\
\mathrm{d}), \mathrm{MPa}\end{array}$ \\
\hline Steel fabrics & 0.169 & 0.538 & 1200 & 3.14 & 3000 & 190 & - & - \\
\hline Geo-mortar & - & - & - & - & $8^{*}$ & 22 & 50 & 2 \\
\hline
\end{tabular}

\subsection{Test beams}

In total, six test beams of the same T-section and span were prepared and tested. Figures $2 \mathrm{a}-2 \mathrm{c}$ show the reinforcement details and geometry of the test beams. The beams had the following geometry: the cross-section height of $400 \mathrm{~mm}$; the flange width of $450 \mathrm{~mm}$; the flange thickness of $100 \mathrm{~mm}$; the web thickness of $300 \mathrm{~mm}$; the total beam length of $2500 \mathrm{~mm}$; and the critical shear span of $950 \mathrm{~mm}$, as shown in Figs. 2a-2c. The longitudinal reinforcement consisted of five $25 \mathrm{~mm}$ diameter bars placed in two rows at the bottom and six $16 \mathrm{~mm}$ diameter bars on the top of the beam. The shear reinforcement involved $8 \mathrm{~mm}$ diameter stirrups spaced at $75 \mathrm{~mm}$ outside the critical shear span, as shown in Figs. 2a-2d.

The beams were grouped into three series based on the number of stirrups within the shear span. The first series was internally unreinforced in shear within the test span, while the second and third series were reinforced with $6 \mathrm{~mm}$ diameter stirrups placed at $300 \mathrm{~mm}$ and $6 \mathrm{~mm}$ stirrups placed at $150 \mathrm{~mm}$, respectively, as shown in Fig. 2c. 


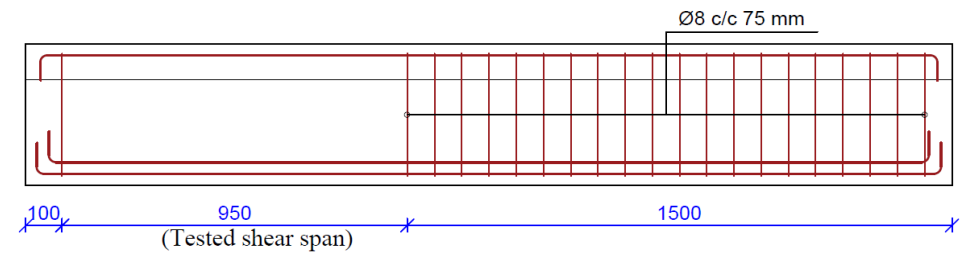

(a)

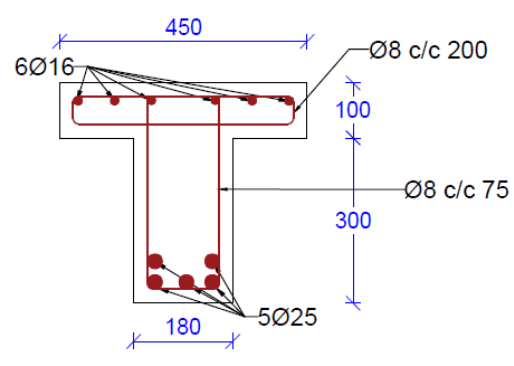

(b)

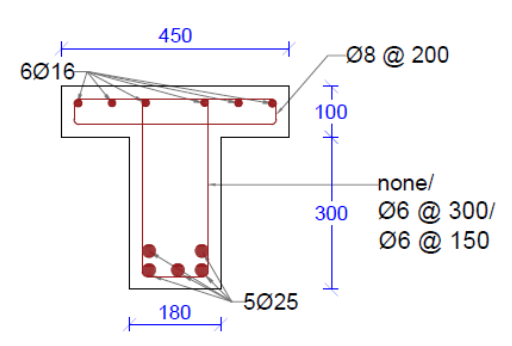

(c)

Figure 2: Reinforcement details and geometry of the test beams: (a) longitudinal detail, (b) cross-sectional detail outside the CSS, and (c) cross-sectional detail within the CSS. (Dimensions: $\mathrm{mm}$ )

\subsection{Strengthening procedures}

Each beam was strengthened with two layers of externally bonded SRG applied in the U-wrapped scheme. The strengthening technique is composed of the following procedures: i) the surface of the test beams was sandblasted and cleaned, ii) the SRG fabrics were cut with the desired length and bent in U-shape, iii) the first layer of mortar was applied on the prepared concrete surface, iv) the first layer of the steel fabrics was installed and fully impregnated with the underlying mortar layer, v) second mortar layer was followed by installation of second fabric layer, and vi) the final mortar layer covered the second layer of the steel fabrics and the SRG final surface was finished. To guarantee proper curing of the SRG composite, at least one month passed between the beam strengthening and test dates.

The details of the tested beams are given in Table 3. Each test beam is designated using Si-X, where, "S" stands for beam series, numeral "I" indicates the beam series, " $\mathrm{X}$ " identifies if the beam is strengthened or control beam (" $\mathrm{C}$ " for control beam, "ST" for strengthened beam).

Table 3: Test matrix

\begin{tabular}{|c|c|c|c|c|c|c|}
\hline Designation & Beam series & $\begin{array}{c}\text { Beam depth } \\
(\mathrm{mm})\end{array}$ & $\begin{array}{c}\text { Beam web } \\
\text { width }(\mathrm{mm})\end{array}$ & $\begin{array}{c}\text { Critical shear } \\
\text { span }(\mathrm{mm})\end{array}$ & $\begin{array}{c}\text { Steel stirrups within } \\
\text { the CSS }\end{array}$ & SRG wraps \\
\hline S1-C & 1 & 400 & 180 & 950 & - & Control \\
\hline S1-ST & 1 & 400 & 180 & 950 & - & U-wrap \\
\hline S2-C & 2 & 400 & 180 & 950 & $6 \mathrm{~mm} @ 300 \mathrm{~mm}$ & Control \\
\hline S2-ST & 2 & 400 & 180 & 950 & $6 \mathrm{~mm} @ 300 \mathrm{~mm}$ & U-wrap \\
\hline S3-C & 3 & 400 & 180 & 950 & $6 \mathrm{~mm} @ 150 \mathrm{~mm}$ & Control \\
\hline S3-ST & 3 & 400 & 180 & 950 & $6 \mathrm{~mm} @ 150 \mathrm{~mm}$ & U-wrap \\
\hline
\end{tabular}




\subsection{Test setup}

The beams were tested under three-point bending using the Instron UTM loading frame, as shown in Fig. 3. The applied load (P) at the loading point was recorded by the load cell. The displacement under the loading point was monitored by using two linear variable displacement transducers placed under the load application point, as shown in Fig. 3. In addition, strain gauges were used to measure the strains in the tensile reinforcement and compressive strains in concrete.

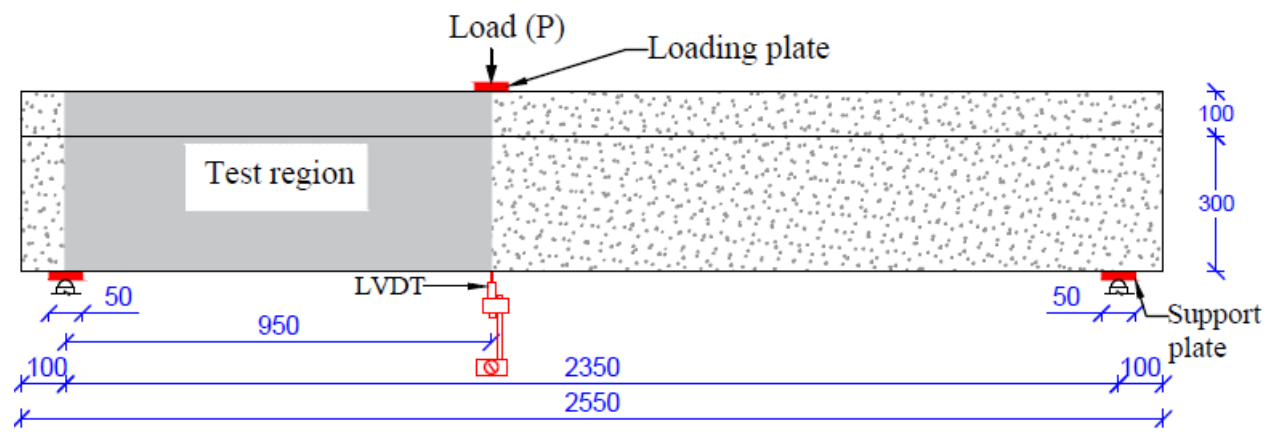

Figure 3: Test setup

\section{RESULTS AND DISCUSSION}

The main test results including the ultimate load $\left(\mathrm{P}_{\mathrm{u}}\right)$, gain in $\mathrm{P}_{\mathrm{u}}$, deflection at $\mathrm{P}_{\mathrm{u}}$, the strains developed in concrete and tensile bars at $\mathrm{P}_{\mathrm{u}}$ are listed in Table 4 and discussed in the following sections.

Table 4: Test results

\begin{tabular}{|c|c|c|c|c|c|}
\hline $\begin{array}{c}\text { Desig- } \\
\text { nation }\end{array}$ & $\begin{array}{c}\text { Ultimate } \\
\text { load }\left(\mathrm{P}_{\mathrm{u}}\right)(\mathrm{kN})\end{array}$ & $\begin{array}{c}\text { In- } \\
\text { crease in } \\
\mathrm{P}_{\mathrm{u}}(\%)\end{array}$ & $\begin{array}{c}\text { De- } \\
\text { flection } \\
\text { at } \mathrm{P}_{\mathrm{u}} \\
(\mathrm{mm})\end{array}$ & $\begin{array}{c}\text { Concrete } \\
\text { strain at } \mathrm{P}_{\mathrm{u}}(\%)\end{array}$ & $\begin{array}{c}\text { Tensile strain in } \\
\text { the longitudinal bar } \\
\text { at } \mathrm{P}_{\mathrm{u}}(\%)\end{array}$ \\
\hline S1-C & 204 & - & 2.39 & 0.430 & 0.789 \\
\hline S1-ST & 349 & 71 & 6.17 & 1.124 & 1.356 \\
\hline S2-C & 283 & - & 6.78 & 0.679 & 1.154 \\
\hline S2-ST & 385 & 36 & 10.0 & 0.817 & 1.513 \\
\hline S3-C & 331 & - & 8.13 & 2.142 & 1.312 \\
\hline S3-ST & 403 & 22 & 11.4 & 0.497 & 1.762 \\
\hline
\end{tabular}

\subsection{Load-deflection responses}

Figure 4 shows the response of load versus deflection under the loading point. Figure 4 and the results included in Table 4 show that the adopted SRG system provided an increase in the beam's shear capacity. The increase in the shear capacity ranged between $22 \%$ and $71 \%$, as listed in Table 4 . The strengthened specimens, namely, S1-ST, S2-ST, and S3-ST failed at the ultimate load of $349 \mathrm{kN}, 385 \mathrm{kN}$, and $403 \mathrm{kN}$, respectively. The 
control beams S1-C, S2-C, and S3-C failed at ultimate load of $204 \mathrm{kN}, 283 \mathrm{kN}$, and 331 $\mathrm{kN}$, respectively.

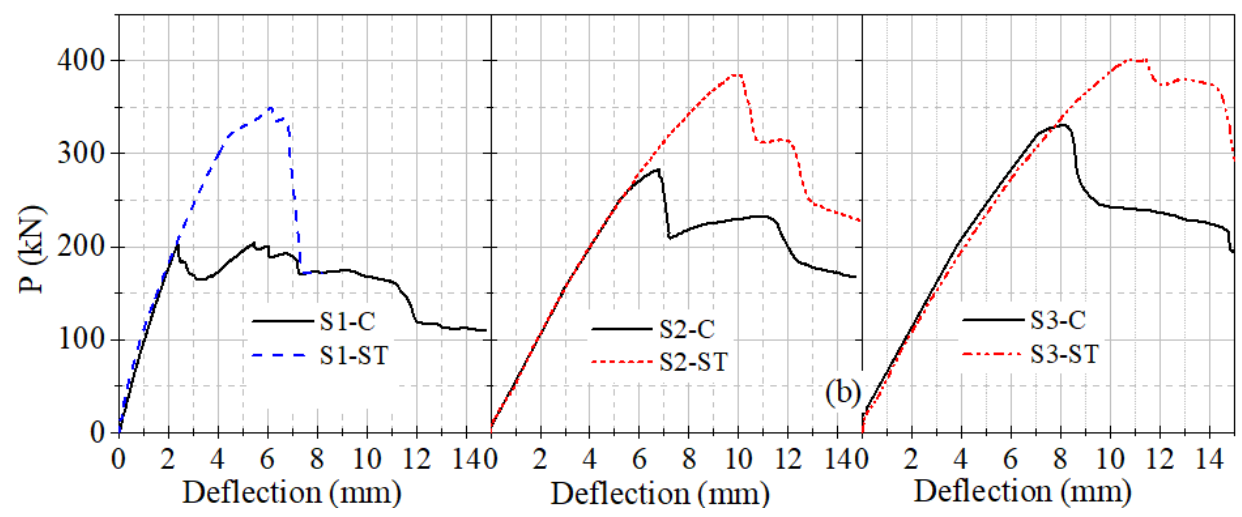

Figure 4: Plots of load versus deflection

\subsection{Failure modes}

The control beams showed a typical shear failure mode of slender beams, as shown in Fig. 5a for Specimen S1-C. The failure in the strengthened beams was characterized by shear failure caused by shear cracks and premature debonding of SRG laminate off the concrete substrate, as can be seen in Fig. 5b for Specimen S2-ST.

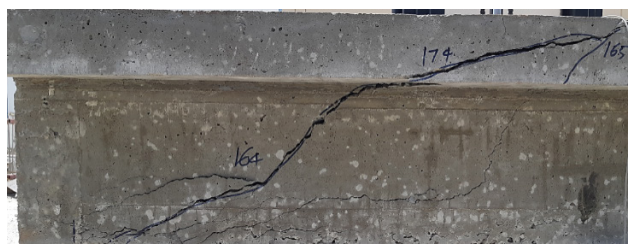

(a) $\mathrm{S} 1-\mathrm{C}$

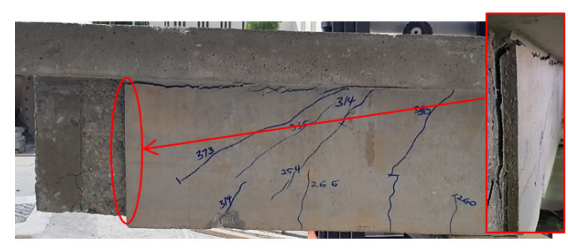

(b) S2-ST

Figure 5: Crack patterns and failure modes observed in the control and strengthened beams

\subsection{Interaction between SRG and steel stirrups}

The strengthened beam without stirrups within the critical shear span, namely Specimen S1-ST, failed at an ultimate load of $349 \mathrm{kN}$ corresponding to $71 \%$ gain in the load-carrying capacity relative to the control beam, S1. The provision of internal shear reinforcement in Specimen S2-ST reduced the gain in the load-carrying capacity due to SRG system compared to Specimen S1-ST with no shear reinforcement in the shear span. Moreover, the gain in the load-carrying capacity was further dropped to $22 \%$ by an increase in the internal shear span within the shear span due to the load sharing between the stirrups and SRG reinforcement. Furthermore, the strengthening system has reduced the strains in the stirrups within the critical shear span compared to that for the corresponding control beam.

\section{CONCLUSION}

The test results of six T-cross section RC beams strengthened in shear with U-wrapped 
SRG system were presented in this paper. The effects of SRG/stirrups interaction were analyzed and compared in terms of load-carrying capacity and failure modes. The test results showed that SRG can be used to substantially increase the load-carrying capacity of RC beam shear-strengthened with SRG U-wraps. The increase in the load-carrying capacity ranging from $22 \%$ to $71 \%$ was observed. The highest increase in the loadcarrying capacity was observed for Specimen S1-ST, without stirrups within the critical shear span. Shear interaction exists between SRG and stirrups. The provision of stirrups within the critical shear span reduced the percentage gain in the load-carrying capacity of the strengthened beams. Further reduction in the percentage gain in the load-carrying capacity was observed with an increase in the internal shear reinforcement within the critical shear span. The strengthened specimens failed in shear caused by premature debonding of SRG laminates.

\section{REFERENCES}

Al-Saadi, N. T. K., Mohammed, A., Al-Mahaidi, R. \& Sanjayan, J. (2019). A state-of-theart review: Near-surface mounted FRP composites for reinforced concrete structures. Construction and Building Materials, 209, 748-769.

Annalisa, N., Roberto, R., Massimo, P. \& Casadei, P. (2015). Flexural strengthening of RC Slabs with SRP/SRG : An experimental-numerical comparison. Applied Mechanics and Materials, 847(October 2017), 381-390.

Barton, B., Wobbe, E., Dharani, L. R., Silva, P., Birman, V., Nanni, A., Alkhrdaji, T., Thomas, J. \& Tunis, G. (2005). Characterization of reinforced concrete beams strengthened by Steel Reinforced Polymer and Grout (SRP and SRG) composites. Materials science and Engineering: A, 412, 129-136.

Bencardino, F. \& Condello, A. (2015). Reliability and adaptability of the analytical models proposed for the FRP systems to the steel reinforced polymer and steel reinforced grout strengthening systems. Composites Part B: Engineering, Elsevier Ltd, 76, 249-259.

Carozzi, F. G., Bellini, A., D’Antino, T., de Felice, G., Focacci, F., Hojdys, Ł., Laghi, L., Lanoye, E., Micelli, F., Panizza, M. \& Poggi, C. (2017). Experimental investigation of tensile and bond properties of Carbon-FRCM composites for strengthening masonry elements. Composites Part B: Engineering, 128, 100-119.

Elsanadedy, H., Abbas, H., Almusallam, T. \& Al-Salloum, Y. (2019). Organic versus inorganic matrix composites for bond-critical strengthening applications of RC structures - State-ofthe-art review. Composites Part B: Engineering, 174.

Hadad, H. \& Nanni, A. (2018). Structural performance of SRG strengthened RC slabs. (August).

Huang, X., Birman, V., Nanni, A. \& Tunis, G. (2005). Properties and potential for application of steel reinforced polymer and steel reinforced grout composites. Composites Part B: Engineering, 36, 73-82.

Koutas, L., Tetta, Z. C., Bournas, D. \& Triantafillou, T. (2019). Strengthening of concrete structures with textile reinforced mortars : State-of-the-art review. Journal of Composites for Construction, 23(1), 03118001.

Marcinczak, D. \& Trapko, T. (2019). Shear strengthening of reinforced concrete beams with PBO-FRCM composites with anchorage. Composites Part B: Engineering, 158(August 2018), 149-161. 
Napoli, A. \& Realfonzo, R. (2015). Reinforced concrete beams strengthened with SRP/SRG systems: Experimental investigation. Construction and Building Materials, Elsevier Ltd, 93, 654-677.

Oller, E., Pujol, M. \& Marí, A. (2019). Contribution of externally bonded FRP shear reinforcement to the shear strength of RC beams. Composites Part B: Engineering, 164, 235-248.

Prota, A., Tan, K. Y., Nanni, A., Pecce, M. \& Manfredi, G. (2006). Performance of shallow reinforced concrete beams with externally bonded steel-reinforced polymer. ACI Structural Journal, 103(2), 163-170.

De Santis, S. \& De Felice, G. (2015). Steel reinforced grout systems for the strengthening of masonry structures. Composite Structures, Elsevier Ltd, 134, 533-548.

De Santis, S., De Felice, G., Napoli, A. \& Realfonzo, R. (2016). Strengthening of structures with Steel reinforced polymers: A State-of-the-art review. Composites Part B: Engineering, Elsevier Ltd, 104, 87-110.

De Santis, S., Roscini, F. \& De Felice, G. (2018). Full-scale tests on masonry vaults strengthened with steel reinforced grout. Composites Part B: Engineering, Elsevier, 141(December 2017), 20-36.

Thermou, G. E. \& Hajirasouliha, I. (2018). Compressive behavior of concrete columns confined with steel-reinforced grout jackets. Composites Part B: Engineering, Elsevier, 138(April 2017), 222-231.

Thermou, G. E., Papanikolaou, V. K., Lioupis, C. \& Hajirasouliha, I. (2019). Steel-Reinforced Grout (SRG) strengthening of shear-critical RC beams. Construction and Building Materials, Elsevier Ltd, 216, 68-83.

Wakjira, T. \& Ebead, U. (2018). Hybrid NSE/EB technique for shear strengthening of reinforced concrete beams using FRCM: Experimental study. Construction and Building Materials, Elsevier Ltd, 164, 164-177.

Wakjira, T. \& Ebead, U. (2019). Experimental and analytical study on strengthening of reinforced concrete T-beams in shear using Steel Reinforced Grout (SRG). Composites Part B: Engineering, 177, 107368.

Wobbe, E., Silva, P., Barton, B. L., Dharani, L. R., Birman, V., Nanni, A., Alkhrdaji, T., Thomas, J. \& Tunis, G. (2004). Flexural capacity of RC beams externally bonded with SRP and SRG. Proceedings of Society for the advancement of material and process engineering Symp., Long Beach, CA, the USA.

Younis, A., Ebead, U. \& Shrestha, K. C. (2017). Different FRCM systems for shear-strengthening of reinforced concrete beams. Construction and Building Materials, 153, 514-526. 